\title{
PRAGMATIC AWARENESS IN TEACHER EDUCATION
}

\section{Renata Povolná}

\section{Klíčová slova:}

pragmatické povědomí, pragmatika, jazykové vzdělávání, výuka jazyků, vzdělávání učitelů, produktivní jazykové dovednosti, receptivní jazykové dovednosti, komunikativní jazykové kompetence, lingvistické kompetence, sociolingvistické kompetence, pragmatické kompetence

\section{Key words:}

pragmatic awareness, pragmatics, language learning, language teaching, teacher education, productive language skills, receptive language skills, communicative language competences, linguistic competences, sociolinguistic competences, pragmatic competences

\begin{abstract}
Abstrakt
Článek přináší výsledky výzkumu, který autorka uskutečnila u několika skupin studentů, a to jak budoucích, tak stávajících učitelů angličtiny. Cílem bylo zjistit, jaký mají tito studenti názor na studium pragmatiky a zda považují kurz o základech pragmatiky za důležitý pro své jazykové vzdělání. Autorka se také pokusila zjistit, zda studenti používají nebo plánují používat ve svém učitelském povolání tzv. pragmatic awareness approach (přístup pragmatického povědomí).

Autorka vychází především z analýzy návrhů studentů, jak lze v učitelské praxi aplikovat teoretické znalosti a praktické dovednosti získané při studiu pragmatiky, a to s ohledem na produktivní a receptivní jazykové dovednosti stejně jako komunikativní jazykové kompetence, tj. lingvistické, sociolingvistické a pragmatické kompetence, které zformuloval Trim (2005) pro společný evropský referenční rámec pro jazyky (Common European Framework of Reference for Languages), protože právě rovnováha mezi produktivními a receptivními jazykovými dovednostmi a zvládnutí komunikativních jazykových kompetencí jsou považovány za nezbytnou součást vzdělávacího procesu.
\end{abstract}

\begin{abstract}
The paper aims to investigate how students as (future) teachers of English view the study of pragmatics and its role in language education, and whether they are ready to adopt a pragmatic awareness approach in their own teaching. The author has analysed students' suggestions about how to use in their teaching the theoretical knowledge and practical skills they have acquired in the Pragmatics course, with special regard to productive and receptive language skills, and the communicative language competences, i.e. the linguistic, sociolinguistic and pragmatic competences, as recognized by Trim (2005) within the Common European Framework of Reference for Languages, since the balance between productive and receptive language skills on the one hand and the mastering of the communicative language competences on the other are regarded as indispensable components of the learning and teaching process.
\end{abstract}

\section{Introduction}

The close interconnection between theory and practice is characteristic of all linguisticsoriented courses taught at the Department of English Language and Literature at the Faculty of Education of Masaryk University, Brno (Povolná 2009a, 2009b). These courses enhance primarily learners' linguistic competences, namely theoretical knowledge and practical skills 
in the areas of phonetics and phonology, grammar, syntax, lexicology, stylistics, and pragmatics; in addition, they develop learners' ability to apply this knowledge in teaching EFL, since without didactic elements the preparation of future teachers of English cannot be successful (Povolná 2004). Accordingly, under the supervision of their teachers students are trained to become able to combine the knowledge of theory they have gathered during their studies at the Department and its practical application in the analysis and interpretation of both spoken and written English discourse. This concerns in particular the Pragmatics course, which, in the present paper, is related to what students as (future) teachers of English really do and whether they are ready to adopt a pragmatic awareness approach in their own teaching.

\section{Pragmatic awareness approach to teaching}

A language awareness approach to teaching foreign languages pays special attention to developing learners' language awareness of how the target language is typically used in communication (Tomlinson 1994). Making explicit what students know implicitly about the system of language and the principles of language use is particularly important in the education of language teachers, since an understanding of how language resources can be used to achieve different communicative goals in both spoken and written communication is indispensable for (future) language teachers: on the one hand it improves their communicative language competences, and on the other it helps them realise what and how they should teach to help their (future) students acquire the target language more effectively and successfully.

The acquisition of pragmatic strategies people use in order to achieve their communicative goals in daily communication is particularly difficult since it requires the contextualization of language use. It is assumed that while the linguistic competences, i.e. knowledge of the language system in its lexical, grammatical, semantic and phonological dimensions and skill in its use (Trim 2005), are at the core of language use and language learning, other communicative language competences, i.e. the sociolinguistic and pragmatic competences, can be promoted by adopting a pragmatic awareness approach to teaching. It should be noted here that in agreement with Trim (2005) the sociolinguistic competences are viewed as the speakers' knowledge of the appropriate ways how to use language in different social situations, including markers of social relations, politeness conventions, certain stereotyped formulae and register differences, while the pragmatic competences are connected above all with the speakers' ability to form meaningful and coherent discourse in different communicative situations.

The pragmatic awareness approach to teaching aims at developing a gradual awareness of the mismatch between the foreign-language-learners' performance and that of proficient users of the language, namely native speakers of English; the problematic features of appropriate language use may thus be identified and their acquisition facilitated (Tomlinson 1994). The access to data representing authentic discourse and meaningful interaction in the target language can foster the learners' gradual development of pragmatic awareness and thus contribute to the learners' independence and promotion of their skills in generalizing and evaluating not only their own language performance, but also that of other speakers (e.g. their students), which is essential for their work as (future) teachers.

\section{Pragmatic awareness}

Pragmatic awareness can be achieved if students are regularly exposed to authentic English and guided to an understanding of the gap between their use of the target language and that of 
proficient language users. Moreover, since " 'noticing' phenomena in L2 is a crucial step towards effective acquisition" (McCarthy 1998: 68), it seems important to supplement the traditional 'Three P's' methodology (Presentation-Practice-Production) with the 'Three I's' methodology (Illustration-Interaction-Induction), where illustration means especially the exposure of these students to examples taken from authentic English, interaction involves talk among students and teachers about language, and induction means drawing conclusions about the way in which the target language is used in communication (McCarthy 1998).

Since language teaching and especially foreign language teacher education is a complex negotiative activity, the teacher's task is "more one of helping students to find a sense of personal meaningfulness in the learning process in a context which is often shaped by perceptions, goals, and priorities of a variety of other participants" (Tudor 2001: 207) and the teacher's roles in communicative language teaching are those of Facilitator of the communication process and participants' tasks.

\section{The Pragmatics course}

The aim of the Pragmatics course taught to students of English at the Faculty of Education, Brno, is to make students aware of the necessity of applying in their own teaching a pragmatic awareness approach so that they can help their (future) pupils, i.e. learners of an L2, develop awareness of how the target language is used in harmony with participants' communicative goals in order to achieve successful communication. However, students as (future) teachers must first become acquainted with this approach and must acquire the adequate knowledge of L2 which, as it is assumed in the paper, only the study of pragmatics and its actual application in teaching can enable them.

The Pragmatics course is a one-term course and its main references are Pragmatics by Yule (1996), Meaning in Interaction. An Introduction to Pragmatics by Thomas (1995), and some chapters from English Grammar for Today: A New Introduction by Leech et al. (1982). For some further practice students are advised to use Pragmatics by Peccei (1999) and for further reading they are recommended selected chapters from An Introduction to Spoken Interaction by Stenström (1994) and Discourse Analysis by Brown and Yule (1983).

The course introduces students to the study of pragmatics, a relatively new branch of linguistics (Mey 2001, Yule 1996), which considers language from the point of view of its users, "especially of the choices they make, the constraints they encounter in using language in social interaction and the effects their use of language has on other participants in the act of communication" (Crystal 1997: 301).

In this respect the study of pragmatics is different especially from the study of syntax and semantics because "only pragmatics allows humans into the analysis" (Yule 1996: 4). The course builds upon students' knowledge and skills from previously studied linguisticsoriented courses, such as Phonetics and Phonology, Grammar, Syntax, Communicative Syntax, Lexicology, and Stylistics. All these courses are closely related not only in the content but also in the methods applied in contact teaching (Povolná 2005). Similarly, for example, to Communicative Syntax (cf. Dontcheva-Navratilova 2005), the Pragmatics course adopts a communicative approach to language teaching (Widdowson 1978) and "pays attention to functional as well as structural aspects of language" (Littlewood 1981: 1). It views pragmatics as the study of 'meaning in interaction' rather than just 'meaning in use' or 'meaning in context', which reflects the view that "meaning is not something which is inherent in the 
words alone, nor is it produced by the speaker alone, nor by the hearer alone." (Thomas 1995: 22). Accordingly, students are taught that pragmatics is not about meaning: it is about making meaning, which is "a dynamic process, involving the negotiation of meaning between speaker and hearer, the context of utterance (physical, social and linguistic) and the meaning potential of an utterance" (Thomas 1995: 22).

Apart from acquainting the students with basic notions from pragmatics the teacher in the Pragmatics course attempts to make the students realize that it is beneficial for them to apply in their own teaching a language awareness approach, more specifically a pragmatic awareness approach since, as it is argued, only in this way can (future) teachers help their pupils develop awareness of how the target language is typically used to achieve successful communication. (For a review of the classroom-based research of the teaching of pragmatics, see Kasper 2001.)

While learning how meaning is negotiated in daily face-to-face communication, students are exposed to examples taken from authentic spoken English (e.g. recordings of authentic data, on-line or printed spoken language corpora) and asked to simulate dialogues from real-life situations and to discuss the similarities and differences between their mother tongue and the target language. This approach enables them to learn how spoken interaction is structurally and strategically organized (cf. Stenström 1994) and helps them realize that just as people vary their language according to whether they are speaking or writing, "they vary it according to factors such as who they are speaking to, in what situation, and what kind of activity the language is being used for" (Leech at al. 1982: 145).

\section{Groups under investigation}

Three groups of students (altogether 151 students in lifelong education programmes) who took the Pragmatics course at the Department of English Language and Literature at the Faculty of Education of Masaryk University, Brno, in the years 2007 and 2008 were asked to prepare suggestions about how to use in their own teaching the knowledge they had acquired during their study of pragmatics. Some of them already had a Master's degree but were not qualified secondary-school teachers (one group of 35 students), while others were still without a Master's degree and in the final year of their studies (two groups of 116 students). Most students in the groups under investigation were women (135 students) and most of them were already teaching at various types of schools, primary as well as secondary, some of them having been practising teachers for more than ten years.

\section{Results and exemplifications}

The following section discusses the most striking results drawn from the analysis of students' suggestions about how to apply in their own teaching the theoretical knowledge and practical skills they have acquired in the Pragmatics course. In addition, some exemplifications of concrete suggestions prepared by students are included. 


\begin{tabular}{|l|c|}
\hline Topics from the study of pragmatics & No. of students \\
\hline Introduction to pragmatics & 32 \\
\hline Deixis and distance & 37 \\
\hline Reference & 31 \\
\hline Presupposition and entailment & 7 \\
\hline The Cooperative Principle & 16 \\
\hline Meaning in interaction & 19 \\
\hline Speech act classification & 11 \\
\hline Speech acts and speech events & 20 \\
\hline Politeness and interaction & 37 \\
\hline Conversational analysis and preference structure & 27 \\
\hline Coherence and cultural schemata & 14 \\
\hline Differences between speech and writing & 11 \\
\hline Total number of topics mentioned by students & $\mathbf{2 6 2}$ \\
\hline
\end{tabular}

Table 1: Topics from the study of pragmatics used in teaching

Table 1 provides a list of the most important topics taught to students in the Pragmatics course. Since the course is an introductory one, only the basic topics from the study of pragmatics are included in the course syllabus. Out of these, deixis, politeness, reference and pragmatic meaning (studied in the introduction to pragmatics) are the topics that are most frequently applied in classroom activities suggested by the three groups of students included in the investigation. (For exemplification, see students' suggestions below.) It must be noted here that the number of topics mentioned by students in their suggestions (262 topics) is much higher than the total number of suggestions (151 suggestions), since only the latter corresponds with the number of students included in the investigation. It necessarily follows that some students were concerned in their suggestions with more than one topics from their study of pragmatics.

\begin{tabular}{|l|c|}
\hline All language skills & No. of students \\
\hline Productive skills - speaking & 97 \\
\hline - writing & 31 \\
\hline Receptive skills - listening & 13 \\
\hline - reading & 7 \\
\hline
\end{tabular}

Table 2: Language skills in which pragmatics topics are applied

As regards the proportion of productive and receptive language skills as reflected in the students' suggestions analysed in this study, we can hardly speak about any balance between the application of the individual skills (see Table 2). What is interesting, though not surprising, is the proportion between skills connected with the spoken language and those with the written language. The overwhelming majority of students (110 students) chose to apply their knowledge and skills acquired in the Pragmatics course either when preparing speaking or when doing listening activities with their pupils, i.e. when enhancing pupils' comprehension of spoken language. Only 38 suggestions prepared by students were related to writing and reading, i.e. practising written language skills. As for the proportion between productive and receptive skills, this is even more striking, since as many as 128 suggestions out of 148 involve productive skills. By contrast, only 20 suggestions prepared by students 
concern receptive skills. This is undoubtedly caused by the fact that students discussed most of the pragmatics topics with their teacher while relating them to the spoken variety of the language and, moreover, they were often asked to simulate authentic spoken dialogues under different contextual conditions, thus practising one of the productive skills - speaking.

Table 3 brings still another comparison, this time between the communicative language competences (see Trim 2005, quoted above), i.e. the linguistic, sociolinguistic and pragmatic competences, notably when related to the activities prepared for pupils by the students on the ground of their study of pragmatics. As can be seen from the table, all the three kinds of communicative language competences, i.e. linguistic, sociolinguistic, and pragmatic, are resorted to with relatively the same frequency (63 to 70 cases). However, the same balance is not the case within the individual competences. For example, within the linguistic competences, students prepared suggestions about how to apply knowledge of pragmatics in particular with regard to grammatical competence (38 out of 63 suggestions). As for the sociolinguistic competences, the highest number of suggestions concerned register differences ( 28 out of 69 found in the data). And finally, concerning the pragmatic competences, it can be stated that students prepared most frequently some classroom activities enhancing their pupils' functional competence (56 out of 70 suggestions).

\begin{tabular}{|l|c|}
\hline Communicative language competences & No. of students \\
\hline Linguistic competences & 63 \\
\hline Lexical competence & 8 \\
\hline Grammatical competence & 38 \\
\hline Semantic competence & 12 \\
\hline Phonological competence & 5 \\
\hline Sociolinguistic competences & 69 \\
\hline Markers of social relations & 9 \\
\hline Politeness conventions & 17 \\
\hline Expressions of folk-wisdom & 4 \\
\hline Register difference & 28 \\
\hline Dialect and accent & 11 \\
\hline Pragmatic competences & 70 \\
\hline Discourse competence & 11 \\
\hline Functional competence & 56 \\
\hline Schematic design competence & 3 \\
\hline
\end{tabular}

Table 3: Communicative language competences (based on Trim 2005)

Let me now exemplify some of the suggestions the students participating in the investigation prepared as part of their course requirements. Owing to the lack of space, only a few can be presented here. It should be noted here that in most of them the exact words used by students are used, which, unfortunately, sometimes entails the use of ungrammatical structures.

Example 1:

One of the students prepared the following suggestion how to apply the knowledge of deixis in speaking:

An interesting thing which I could use in my teaching is psychological distance. This means that we show our attitudes to things through using some specific words. 
I am particularly interested in the use of that when we want to express that we do not like something and this when we like something.

Step 1

I would introduce the matter by asking my students a model question: Do you like this handbag? (I teach mostly girls.) and I would show them a picture of a handbag from a magazine. They would definitely answer Yes / No / or Yes, I do. / No, I don't.

Step 2

I would write these two answers on the board: I like this. / I don't like that. and I would ask them why I used this and that in the particular sentences. My explanation would be that this is used when we like something and that when we want to express that we do not like it. I would probably use some face gestures at the same time (this - I would look very enthusiastically and that - I would look disgusted), or I would draw such easy faces on the board.

That

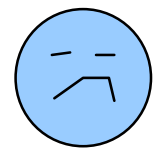

This

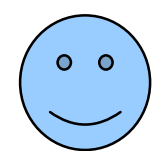

\section{Step 3}

I would give every student one picture with some clothes from fashion magazines and their task would be to stand up and ask the other students in class if they like it. The model dialog would be like this:

A: Do you like this? (a picture of a dress)

B: I don't like that. / I like this. (+ appropriate face)

Step 4

Students would write this issue into their exercise books together with the two faces to remember it more clearly.

Example 2:

Another student concentrated on the application of the knowledge of politeness formula in speaking:

How to teach politeness in English-speaking context

(The target country is Great Britain and interaction is intended to be realized between speakers of different status.)

\section{The HOW TO BE BRITISH collection}
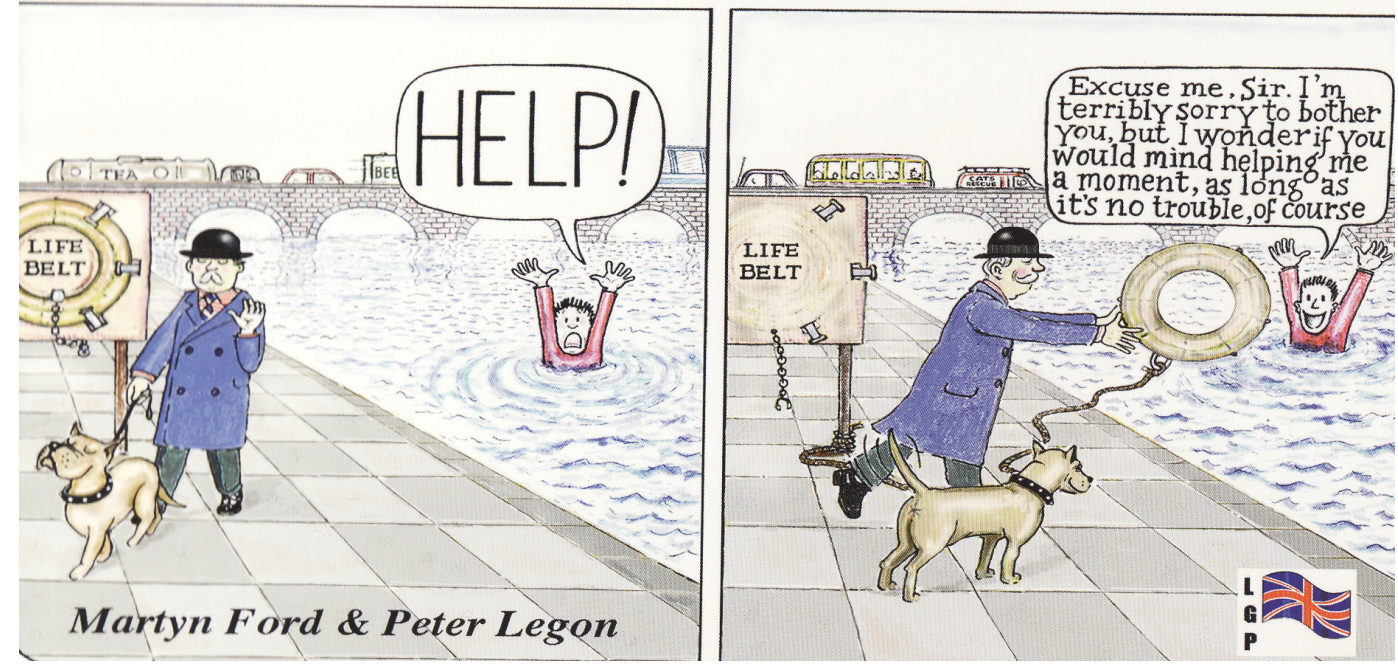
British people are well-known for their politeness. Although they are able to make fun of themselves and their politeness, teacher must get learners aware of different situations of social distance or closeness. Pupils often learn sentences from conversation in films or video records. To use such utterances in conversation between people who are not good friends, who are not close, who are not of the same social status carries some danger. Speaker can be considered impolite and can be refused by the listeners. Teacher must lead learners to avoid such situation teaching them the most suitable expressions and ways how to communicate correctly. Young learners coming to the target language country must know how to be polite. They usually do not know people of the country, they are not close friends for them, they are of lower status and this is the reason for being cautious when they are e.g. asking for help, for services, a favour. Teachers must teach learners to use negative politeness strategies which are typically expressed via questions. I think it is not necessary to teach positive politeness strategies at school. These are naturally learnt among friends, among members of the group, among people that have something in common. But students must be able to distinguish what is negative politeness and what is positive politeness or, in the case of younger pupils, which form of request is used in situation when they are speaking with adult or unknown people.

Task: Try to choose the most suitable way how to express request in a given situation:

"Could you lend me your....., please?", "I'm sorry to bother you, but....", "May I use your phone?", "Would you be so kind...?”, "Will you ......?", "Would you please tell me...?",

"Can anyone tell me......?", "I wonder if you could.....", "Would you be kind enough to let me know?", "Would you mind my...............?" etc.

Learners are provided with examples from real life situations. Speakers are either close friends or persons of different social status (different age, position, ...).

e.g. - You are in a waiting room with many unknown people and you would like to open the window or ask somebody to do it.

- You want to fill in the form at the post office. You do not have a pen and there is no pen at disposal.

- You have left your pencil case at home. Ask your neighbour for a favour. etc.

\section{Example 3:}

Still another student (a male teacher) prepared a suggestion about how to use the knowledge of politeness principles in speaking:

The range of activities focusing on the basic pragmatic principles that can be done in class is very wide, of course. I would like to mention ... examples of such activities. The first one revolves around the politeness principles. Children do not need to know terms such as face wants or positive/negative politeness, so in actual practice the principles can be simplified. What is most important is that children learn to react appropriately in specific social situations - e.g. they are able to use a suitable response to a request, they can judge what tone the situation requires - whether it is possible to be informal or not, etc.

I would design the activity as a role-play to simulate a real situation. It could be done as a pair activity. One student in the pair would be the requester - he/she would get a piece of paper with a directive such as - 'ask your colleague about time' or 'ask if you can open a window' etc. The other student's piece of paper would contain a short description of his/her emotional state at the moment - i.e. how they should act - e.g. 'you have a really bad day today and are angry' or 'you are in a hurry because you want to catch your bus', etc. Then they would simply act this short dialogue or request/response in the pairs - the first student would come up with a request according to the given criteria - 'Excuse me, could you tell me what's the time, please?' and the other would react in accordance with his/her character's emotional state 
- 'No, I couldn't.', 'I'm sorry, I don't have time.' or simply 'It's quarter past three.' or 'Of course, let me check my watch. It's five to twelve, almost time for lunch.' I would give the students a minute or two to prepare their requests and responses in pairs and then we would act the situations one at a time in front of the class and we could try to decide whether the response was appropriate, etc.

Examples of the requests given to the students:

- ask if you can open a window;

- ask for directions to the nearest hospital;

- ask if you can get the seat by the window;

- ask if the person can answer a few questions for a survey;

- ask if you can borrow a tissue, etc.

\section{Students' opinions on the study of pragmatics}

In order to illustrate how students themselves view the study of pragmatics and in particular whether they consider it useful for their future profession, the following section lists some of the opinions students included in their suggestions. It must be stated here that students were not asked to express their opinions of pragmatics in their suggestions, but still some of them felt it necessary to do so, in particular those who first considered the Pragmatics course irrelevant for their (future) teacher's profession.

To be honest, firstly I thought I would never ever include some principles of Pragmatics into my English lessons at primary school. Fortunately, ... I have changed my mind. Now, after participating in your course I really enriched my own feeling for language. I mean that now I can see behind and above language.

At the beginning of the course I thought it was not as useful for me as it revealed during and at the end of it.... I would like to say that pragmatics is a very interesting and useful science and opens up the door for deeper knowledge of English.

I liked the subject because I have learnt a lot of valuable information about communication, speech, conversation, relations among speakers and listeners. ... after finishing university I will be a beginning teacher and the knowledge of above mentioned principles will certainly help me avoid the communication misunderstandings.

To sum up, I find the things we have learned very useful not only for me, but I think that it will help me explain some things to my students in a better and more efficient way. It definitely enriched my knowledge.

What may seemingly appear to be a subject of merely theoretical study can also be made use of in many cases of English language teaching methodology.

When thinking about teaching English, it is definitely a good thing to have some knowledge of pragmatics as we can employ it basically in every English lesson and thereby make our students think about the English language from another point of view as well.

It follows from the above-listed opinions presented only anonymously here that students in general consider the study of pragmatics important not only for their own language proficiency but also for their profession and, moreover, they are ready to use the knowledge and skills acquired in the Pragmatics course in their own teaching, which in my opinion is possible (and students are well aware of it) only if they apply a pragmatic awareness approach to language teaching. 


\section{Conclusions}

Based on the analysis of the students' suggestions it can now be concluded that:

1. students as (future) teachers of English benefit from the study of pragmatics and are ready to apply most of their theoretical knowledge as well as practical skills in their own teaching; this concerns above all topics such as deixis and politeness which are taught in the Pragmatics course;

2. students consider enhancing pragmatic awareness in their pupils important and a pragmatic approach to teaching appropriate in communicative language teaching, in particular when fostering pupils' productive language skills such as speaking; and

3. students related their suggestions about how to use pragmatics in teaching most frequently to enhancing pupils' grammatical competence within linguistic competences, register differences and politeness conventions within sociolinguistic competences, and functional competence within pragmatic competences.

Finally, it should be stated that the investigation has proved the importance of the study of pragmatics and the necessity of integrating didactic elements into linguistics-oriented courses above all in education programmes for future teachers.

\section{Literature:}

[1] BROWN, G., YULE, G. Discourse Analysis. Cambridge Textbooks in Linguistics. Cambridge: Cambridge University Press, 1983, 288 pp. ISBN: 0-521-28475-9.

[2] CRYSTAL, D. (ed.) The Cambridge Encyclopedia of the Language. $2^{\text {nd }}$ ed. New York: Cambridge University Press, 1997, 489 pp. ISBN: 0-521-40179-8.

[3] DONTCHEVA-NAVRATILOVA, O. Grammatical Structures in English: Meaning in Context. $2^{\text {nd }}$ ed. Brno: Masaryk university, 2005, 166 pp. ISBN: 80-210-3849-7.

[4] KASPER, G. 'Classroom research on interlanguage pragmatics.' In: Rose, K. R., Kasper, G. (eds) Pragmatics in Language Teaching. Cambridge: Cambridge University Press, 2001, 33-60, ISBN: 0-521-00858-1.

[5] LEECH, G., DEUCHAR, M., HOOGENRAAD, R. English Grammar for Today: A New Introduction. London: Macmillan Press Ltd., 1982, 224 pp. ISBN: 0-333-30644-9.

[6] LEECH, G., SVARTVIK, J. A Communicative Grammar of English. $2^{\text {nd }}$ ed. London: Longman, 1994, 423 pp. ISBN: 0-582-08573-X.

[7] LITTLEWOOD, W. Communicative Language Teaching. Cambridge: Cambridge University Press. 1981. 108 pp. ISBN: 0-521-28154-7.

[8] McCARTHY, M. Spoken Language and Applied Linguistics. Cambridge: Cambridge University Press. 1998. 206 pp. 0-521-59769-2.

[9] MEY, J. L. Pragmatics. An Introduction. $2^{\text {nd }}$ ed. Oxford: Blackwell Publishers, 2001, 392 pp. ISBN: 0-631-21131-4.

[10] NIEZGODA, K., RÖVER, C. 'Pragmatic and grammatical awareness.' In: Rose, K. R., Kasper, G. (eds) Pragmatics in Language Teaching. Cambridge: Cambridge University Press, 2001, 63-79, ISBN: 0-521-00858-1.

[11] PECCEI, J. S. Pragmatics. London: Routledge, 1999, 96 pp. ISBN: 0-415-20523-9.

[12] POVOLNÁ, R. 'Linguistics research at the Department of English Language and Literature.' In: Hanušová et al. Research in English Language Teacher Education. Brno: Masaryk University, 2009a, 11-18. ISBN: 978-80-210-4967-3.

[13] POVOLNÁ, R. 'Pragmatic awareness and its role in teacher education.' Vienna English Working Papers. Vienna: Institut für Anglistik \& Amerikanistik, Austria, Vol. 4, No 3, 2009b, 111-114. 
[14] POVOLNÁ, R. 'Some linguistics-oriented courses and their contribution to the preparation of future teachers of English.' In: Schmied, J., Haase, C., Voigt, K. (eds) English for Central Europe: Interdisciplinary Saxon-Czech Perspectives. Research in English and Applied Linguistics. REAL Studies 1. Göttingen: Cuvillier Verlag Göttingen, 2005, 63-68. ISBN: 3-86537-420-4.

[15] STENSTRÖM, A.-B. An Introduction to Spoken Interaction. London: Longman, 1994, 238 pp. ISBN: 0-582-07130-5.

[16] THOMAS, J. Meaning in Interaction. An Introduction to Pragmatics. London and New York: Longman, 1995, 224 pp. ISBN: 0-582-29151-8.

[17] TOMLINSON, B. 'Pragmatic awareness activities.' Language Awareness, Vol 3: 3\&4, 1994, 221-236. ISSN: 0965-8416.

[18] TRIM, J. L. M. 'The Role of the Common European Framework of Reference for Languages in Teacher Training.' Lecture delivered in Graz, September 2005. http://www.ecml.at/document/press/trim.pdf.

[19] TUDOR, I. The Dynamics of the Language Classroom. Cambridge: Cambridge University Press, 2001, 234 pp. ISBN: 0-521-77676-7.

[20] WIDDOWSON, H. G. Teaching Language as Communication. Oxford: Oxford University Press, 1978, 168 pp. ISBN: 0-194-37077-1.

[21] YULE, G. Pragmatics. Oxford Introductions to Language Study. Oxford: Oxford University Press, 1996, 138 pp. ISBN: 0-19-437207-3.

\section{JEL I21}

doc. PhDr. Renata Povolná, Ph.D.

Katedra anglického jazyka a literatury

Pedagogická fakulta

Masarykova univerzita

Poříčí 9, 60300 Brno

renata.povolna@volny.cz 